\title{
Extra-Abdominal Aggressive Fibromatosis Presenting As an Intrathoracic Tumor
}

\author{
Intratorasik Ekstra Abdominal Agresif Fibromatozis
}

\author{
Yener YÖRÜK, Yekta Altemur KARAMUSTAFAOĞLU, Yavuz Atakan SEZER ${ }^{1}$, Abdil Cem İBiŞ̧${ }^{1}$ \\ Departments of Thoracic Surgery and General Surgery ${ }^{1}$, Medical Faculty of Trakya University, Edirne
}

Submitted / Başvuru tarihi: 06.08.2008 Accepted / Kabul tarihi: 26.10.2008

\begin{abstract}
Tumors of fibrous tissue origin (fibromatosis) in chest and mediastinum have been rarely reported in the literature. Herein, we report a rare case of aggressive fibromatosis presenting as an intrathoracic tumor. A 36-year-old woman admitted to our hospital due to a feeling of oppression and pain in the left chest. A chest X-ray, thorax computed tomography revealed a large mass filling two thirds of lower left thorax. Widely surgical resection of the tumor was performed thoracotomy via seventh intercostal space. The tumor was $20 \times 15 \times 15 \mathrm{~mm}$ in size and diagnosed pathologically as aggressive fibromatosis. The patient has been well without recurrence for 15 months after surgery.
\end{abstract}

Key words: Aggressive fibromatosis; desmoid tumor.
Fibröz doku kaynaklı tümörler toraksta ve mediastinumda nadir olarak görülmekte ve rapor edilmektedirler. Biz burada, agresif fibromatozisin, toraks içi dokulardan kaynaklanan nadir bir formunu bildirmek istedik. Otuz altı yaşında bayan hasta hastanemize sol göğüs ağrısı ve sıkışma hissi ile başvurdu. Çekilen PA grafi ve toraks bilgisayarlı tomografisinde, sol toraks alt kısmını üçte iki oranında dolduran dev kitle görüldü. Bunun üzerine hastaya sol yedinci interkostal aralıktan yapılan torakotomi ile geniş rezeksiyon uygulandı. Tümör patolojisi $20 \times 15 \times 15 \mathrm{~cm}$ çapında agresif fibromatozis olarak geldi. Hasta 15 aydır takip altında ve kontrollerinde yineleme görülmedi.

Anahtar sözcükler: Agresif fibromatozis; desmoid tümör.
Aggressive fibromatosis is a rarely seen soft tissue
tumor and originate principally from deep seated
fascial or musculoaponeurotic structures. ${ }^{[1]}$ Tumors
of fibrous tissue origin (fibromatosis) in chest and
mediastinum have been rarely reported in the litera-
ture..$^{[1-9]}$ They are characterized by the proliferation of
fibroblasts with no cytological evidence of malignancy
and are organized in the form of fasciae. Aggressive
fibromatosis are considered low-grade malignant sar-
comas. Locally invasive, they tend to recur increasing
morbidity or even mortality. The cause is unknown (trauma, hormonal factors, genetic anomaly). ${ }^{[2]}$ Wide radical resection should be attempted whenever possible. In cases of recurrences, multimodality therapies should be considered.

\section{CASE REPORT}

A case of an extra-abdominal desmoid tumor presenting as an intrathoracic tumor in a 36-year-old woman is reported. She was admitted to our hospital general surgery department with left chest wall pain and feeling of oppression in the left chest. On percussion, a dull

Presented at the 29th National Congress of the Turkish Respiratory Research Society, October 28-31, 2007, Fethiye, Turkey (29. Türkiye Solunum Araştırmaları Derneği Ulusal Kongresi'nde sunulmuştur, 28-31 Ekim 2007, Fethiye).

Correspondence (iletişim adresi): Dr. Yekta Altemur Karamustafaoğlu. Trakya Üniversitesi Tıp Fakültesi, Göğüs Cerrahi Anabilim Dalı, Kat:4, Balkan Yerleşkesi 22030, Edirne. Tel: 0284 - 2355936 Fax (Faks):0284-2355936 e-mail (e-posta): altemurk@hotmail.com

(๑) Trakya Üniversitesi Tıp Fakültesi Dergisi. Ekin Tibbi Yayıncllık tarafından basılmışıı. Her hakkı saklıdır.

(- Medical Journal of Trakya University. Published by Ekin Medical Publishing. All rights reserved. 


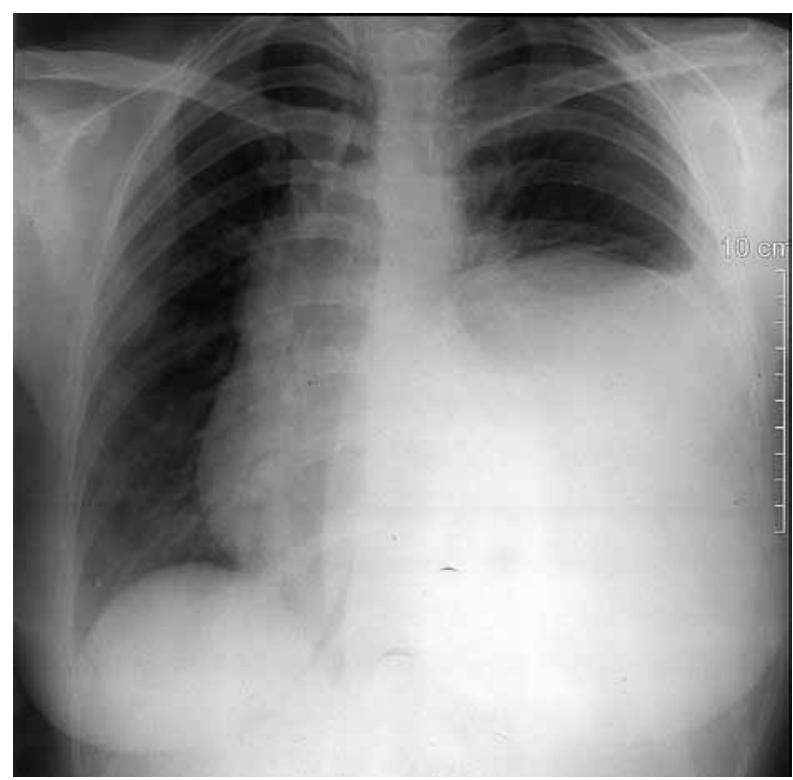

Fig. 1. X-ray showed large mass in the left lower zone.

sound was found in the left lower zone of the chest. Auscultation revealed normal cardiac sounds and normal breathing sounds on the right side and upper left side of the chest. Abdominal examination revealed no palpable masses or other abnormalities and abdominal computed tomography (CT) was normal. A chest X-ray revealed a large homogenous opacity filling two thirds of lower left thorax (Fig. 1). Computed tomography (CT) imaging showed a mass with a dimension of $20 \times 15 \times 15 \mathrm{~cm}$, started at the level of thoracal sixth vertebra reaching the L1-L2 vertebra and specially in supradiapraghmatic level mediastinum invaded with tumor (Fig. 2). Fine needle biopsy had been performed by general surgeons had revealed diagnosis of mesenchymal tumor. Left thoracotomy was performed via seventh intercostal space. At the operation, huge extrapulmonary mass was seen protruding from eleventh and twelfth rib extending to mediastinum posterolaterally. There were no adhesions and invasion to descending aorta and hilum. The mass was completely resected with the invaded eleventh and twelfth ribs and with adjacent partial diaphragma. Postoperative course was uneventful. All surgical margins were tumor free. The immunohistochemical examination showed that the cytoplasms of the tumor cells were strongly positive for vimentin, some tumor cells were positive for alphasmooth muscle actin, but all tumor cells were negative for CD34. So these findings suggested intrathoracic extrapulmonary aggressive fibromatosis. Patient is well in 15 months follow-up.

\section{CONCLUSION}

Aggressive fibromatosis is a rarely seen soft tissue tumor. According to Enzinger and Weiss, ${ }^{[3]}$ fibromatosis can be divided into superficial and deep types. The deep type of fibromatoses the one that would affect the mediastinum is extra-abdominal fibromatosis (extra-abdominal desmoid tumour). Desmoid tumors are uncommon fibromatous tumors arising from musculoaponeurotic tissue characterized by spindle cell fibroblast and myofibroblast proliferation. The cause is unknown. The radiographic findings of desmoids are variable. CT usually shows either a well-circumscribed or an ill-defined soft tissue density of variable attenuation when compared with muscle tissue. After the administration of contrasts, the attenuation may be higher than adjacent muscle tissue. ${ }^{[4]}$ Desmoid tumors are considered benign because of their cytological features and because they don't give rise to metastases, but their biological behavior is that of a locally aggressive tumour. They do recur locally if they are not completely excised of which is not infrequent after surgical resection. ${ }^{[5,6]}$ Fibromatosis like tumors could arise from pleura and constitue $5 \%$ of all pleural tumors. ${ }^{[9]}$ Such tumors are usually solitary and multifocal tumors are not commonly reported. They should be treated by complete excision. Resection must be as radi-

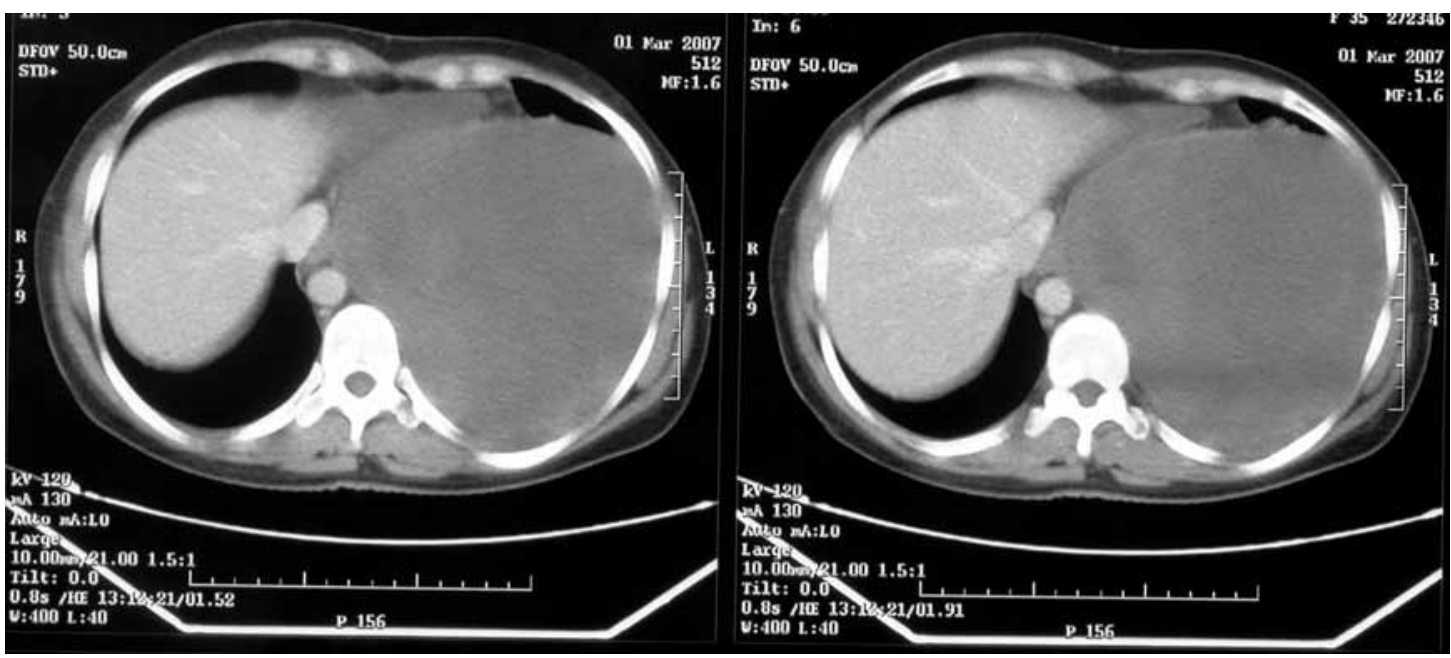

Fig. 2. Computerised tomography revealed large mass in the left thorax. 
cal as possible. Partial resection of a desmoid tumour has been reported but the residual tumour was present at one year follow-up. ${ }^{[5,7]}$ The follow-up of long term is necessary because it may recur. We performed surgical resection with wide free margin excision in our case with no recurrence during 15 months. Chemotherapy and hormonal treatment of non-resectable tumors has been described without convincing results and more data from clinical studies are needed. ${ }^{[8]}$

\section{REFERENCES}

1. Posner MC, Shiu MH, Newsome JL, Hajdu SI, Gaynor JJ, Brennan MF. The desmoid tumor. Not a benign disease. Arch Surg 1989;124:191-6.

2. Giraudet-Le Quintrec JS, Minoui A, Frenaux E, Anract P, Fadel E, Missenard G, et al. Desmoid tumor of the thoracic wall. A case manifesting as painful stiffness of the shoulder. Presse Med 1998;27:1727-30. [Abstract]

3. Enzinger FM, Weiss Sw. Fibrohistiocytic tumors of intermediate malignancy. In: Enzinger FM, Weiss SW, eds. 3rd ed.
St Louis: CV Mosby. 1995. p. 325-49.

4. Shields TW, Robinson PG. Mesenchymal tumors of the mediastinum. In: Shields TW, LoCicero J, Ponn RB, Rusch VW, editors. General thoracic surgery. Vol. 2, 6th ed. Philadelphia: Lippincott Williams and Wilkins; 2005. p. 2786-811.

5. Easter DW, Halasz NA. Recent trends in the management of desmoid tumors. Summary of 19 cases and review of the literature. Ann Surg 1989;210:765-9.

6. Reitamo JJ, Scheinin TM, Häyry P. The desmoid syndrome. New aspects in the cause, pathogenesis and treatment of the desmoid tumor. Am J Surg 1986;151:230-7.

7. Wilson RW, Gallateau-Salle F, Moran CA. Desmoid tumors of the pleura: a clinicopathologic mimic of localized fibrous tumor. Mod Pathol 1999;12:9-14.

8. Sørensen A, Keller JØ, Nielsen OS, Jensen OM. Agressive fibromatosis. Ugeskr Laeger 2000;162:6676-8. [Abstract]

9. Vara Prasad RM, Thankachen R, Parihar B, Viayak S, Korula RJ. Mediastinal fibromatosis- A Case report. Abstract. Ind J Thorac and Cardiovasc Surg 2003;19:203. 